\title{
Intraindividual consistencies in cross-modal matching across several continua
}

\author{
ROBIN DANING \\ University of New Hampshire, Durham, New Hampshire
}

\begin{abstract}
To determine the relationship between individual exponents for cross-modal stimulus matches for both directions of matching, and to assess the transitivity of individual exponents, subjects were asked to adjust both the judgment and criterion stimuli. Experiment 1 involved four continua paired in 12 ordered combinations; Experiment 2 involved five continua and 20 ordered combinations. Two subjects served in each experiment. The individual exponent of the power function for matches of $A$ to $B$ was close to the inverse of the exponent for matches of $B$ to $A$, but there was systematic deviation, indicating the presence of a small regression effect. Transitivity of individual exponents was determined by forming ratios of exponents from matches involving other continuum pairs to predict obtained exponents; the means of the distribution of deviations of obtained from predicted values was $-.02 \mathrm{log}$ units, and the standard deviation was .15 log units, indicating that, on the average, predicted values were close to obtained exponents-that is, transitivity of exponents holds for individuals.
\end{abstract}

When subjects are asked to match values on one stimulus continuum to values on another (e.g., sound . intensity to finger span, weight to length), their judgments are typically a power function of the criterion values (see, e.g., Stevens, 1975). There are two questions about the exponents of power functions that result from cross-modality matching that have yet to be answered satisfactorily. The first is whether the exponent obtained when Continuum $\mathbf{A}$ is matched to Continuum $B\left(A_{2} / B_{1}\right)$ predicts the exponent when the direction of matching is reversed $\left(B_{2} / A_{1}\right)$. The second question centers around the ability to predict the exponent for match $A_{2} / B_{1}$ from the obtained exponents for matches $C_{2} / A_{1}$ and $C_{2} / B_{1}$.

The initial answer to both questions has been that predicted exponents are not the same as obtained exponents. Stevens and Greenbaum (1966), for a variety of continua, compared the exponent $i$ from match $A_{2} / B_{1}$ with the exponent $j$ from match $B_{2} / A_{1}$ : The expected equality $i=1 / j$ was not obtained, and in each case $1 / j$ was larger than $i$. Stevens and Greenbaum (1966) argued that regression depends upon the fact that the subject controls only onethe judgment-stimulus, and that he/she tends to constrict the range of that stimulus. Teghtsoonian and Teghtsoonian (1978) confirmed the existence of the regression effect for two continua for several stimulus ranges; they found that for small ranges (less than $.5 \log$ units) $1 / \mathrm{j}$ was sometimes less than $\mathrm{i}$.

I would like to thank Editor Martha Teghtsoonian emphatically for investing so much time in this paper, and Tony Nevin, for his encouragement. Correspondence should be addressed to Ms. Robin Daning, Department of Psychology, University of New Hampshire, Durham, New Hampshire 03824.
They argued that observers tend to avoid extreme judgment ratios, both large and small, so that neither $i$ nor $1 / j$ is a bias-free estimate of the $A B$ exponent.

If the regression effect arises from the response biases proposed, perhaps it would be possible to eliminate it by permitting subjects to control not only the judgment, but also the criterion stimulus. Constriction of range, or avoidance of extreme ratios, should occur on both continua and effectively cancel each other. Stevens and Guirao (1964) conducted an experiment in which subjects were asked to adjust a tone and then to match a number to it. The subjects were allowed to choose the number first or to combine strategies if they wished. However, the experiment did not interchange identities of the criterion and judgment stimuli, so it was not possible to assess the extent of any regression effect.

The second issue, that of exponent transitivity, also involves the presence of the regression effect. Mashour and Hosman (1968) conducted a crossmodality matching experiment in which exponents obtained from magnitude estimation were compared with those obtained through cross-modality matching for a number of continua. The comparison showed little agreement, and Mashour and Hosman concluded that both the power law and the subjective ratio scales were invalid. Stevens (1969) responded to this conclusion by pointing out that when the exponents obtained by magnitude estimation were corrected for regression, the discrepancies were greatly reduced. Here, again, it becomes clear that a balanced design is vital in order to make an accurate assessment of exponent transitivity.

In the present experiment, the subjects made matches between several continua while controlling both the 
judgment and criterion stimuli, thus making it possible-regardless of outcome-to assess the extent of the regression effect and the transitivity of exponents in individual subjects. Also examined was the relation between regression and subject-selected range.

\section{METHOD}

\section{Subjects}

There were two subjects in Experiment 1, a 31-year-old man with previous experience and a 34-year-old woman. Two women, aged 21 and 50 years, participated in Experiment 2.

\section{Apparatus and Procedure}

Sound intensity. A $1000-\mathrm{Hz}$ tone set at $100 \mathrm{~dB}$ re $20 \mu \mathrm{N} / \mathrm{m}^{2}$ was generated by an audio oscillator (Hewlett-Packard) positioned so its dials were not visible to the subject. Two attenuators of different scale ( 1 and $10 \mathrm{~dB}$ ) varied the intensity from 0 to $100 \mathrm{~dB}$. Tone onset was controlled by an electric switch (set at $25 \mathrm{msec}$ ). The tone was presented binaurally in Experiment 1 and monaurally in Experiment 2 through headphones (Telephonics) by the subject's pressing a telegraph key.

Light intensity. On the table and about $46 \mathrm{~cm}(18$ in.) from the subject, a $30-\mathrm{cm}$ (12-in.) open-ended box held an ordinary 200-W bulb. Several layers of tracing paper, secured to a Plexiglas front, diffused the light. A Variac (General Radio) was used for continuous intensity adjustment from 0 to $1,678 \mathrm{~cd} / \mathrm{m}^{2}$. The door to the testing room was kept open enough to provide dim general illumination. As soon as the subject made a determination, the intensity was reduced to zero by the experimenter. Each stimulus presentation was delayed until the subject claimed he/she had readapted to the general illumination.

Weight. About $5 \mathrm{~kg}$ of .25-cm-diam lead shot was contained in an 8-liter bowl. The subjects scooped shot into a 275-g-capacity plastic container to produce the desired weight. Bowl and container were placed in front of the subject, who was asked to look away while making judgments. The subjects were free to hold the container (with its chosen weight) while matching a stimulus to it, but were asked not to look inside the container. After each trial, the container was given to the experimenter.

Line length. In Experiment 1 , the subjects drew on sheets of paper, $8 \times 22 \mathrm{~cm}$. In Experiment 2, the sheets were $8 \times 29 \mathrm{~cm}$. The subjects were asked before the test if the sheet size seemed suitable for any lines drawn and were told that they would be provided with larger sheets any time they thought it was necessary. The subjects used either pen or pencil.

Finger span. A triangular $92 \times 5 \mathrm{~cm}$ wooden block, from .08 to $17 \mathrm{~cm}$ thick, was calibrated on the side facing the experimenter. To insure tactile, rather than visual, judgment, a wooden barrier about $30 \mathrm{~cm}$ high and the length of the testing table (where the block was located) was placed between the subject and the block. The subject was asked to use the same fingers on the same hand for each determination. The subject was free to refer to either end of the block in making a judgment.

For each of the $A_{2} / B_{1}$ test trials, the subject was to adjust (or to instruct the experimenter to adjust) stimulus $B_{1}$ and then to adjust (or to instruct the experimenter to adjust) stimulus $A_{2}$, so that the perceived intensity of $A_{2}$ was proportional to the perceived intensity of $\mathbf{B}_{1}$. General instructions were:

"Please choose (or draw) a __. ." [In tests with tone intensity and/or light intensity: "The adjustments will be made by me and not you, to prevent any familiarization with the relative knob positions (light) and/or number of clicks (tone). For this reason you will hear me make extra clicks while making adjustments for you. I will make adjustments according to your verbal instructions of 'more' or 'less' until you are satisfied with an intensity."'

"When you are satisfied with your choice, please choose (or draw) a that is proportional to the it." (For tone and/or light intensity, same as above.)

"Remember, it is important for you to be as satisfied as possible with each match, so take your time. You are free to do a trial over if it does not 'feel right.' Also, try to use a wide range of stimulus values." (For tone and/or light intensity: "At any time you may ask to hear/see the greatest or least intensity if you need some reference point.")

The subjects involved in this experiment were asked to make unusual judgments without assistance or feedback. Subjects often complained: "I am not sure if I am doing this correctly." To influence the subjects as little as possible and to avoid a situation in which the subjects were preoccupied with the "success" or "failure" of the tests, a useful reply was "This experiment may seem unusual to you, but, if you can allow your perceptions to guide you, the tests will be a success."

Experiment 1 involved line length, light intensity, sound intensity, and number, paired in 12 possible combinations. Each of these continuum pairs was presented in 20-trial blocks, constituting a test.

Experiment 2 involved the continua of line length, number, sound intensity, finger span, and weight, paired in 20 ordered combinations. Each of the 20 tests was presented in 15-trial blocks.

Before a test began, but after the instructions were given, the subject was free to do practice trials. A practice trial was conducted just as a test trial, with the subject adjusting (or having the experimenter adjust) the criterion stimulus $\left(B_{1}\right)$ and then adjusting the judgment stimulus $\left(A_{2}\right)$ to match it. The subjects averaged one practice trial per test for both experiments.

Except for the number of continua used, Experiments 1 and 2 were conducted identically. In a typical trial (e.g., weight/finger span), the following sequence occurred. (1) The subject placed his/ her fingers on both sides of the block, sliding them along until a desired finger span was found; the experimenter recorded the value. (2) With his/her fingers still on the block at the same spot, the subject then picked up container No. 1 with the other hand and began scooping (and dumping) the shot until a desired weight was found; the experimenter then took the container, which she weighed at a later time. (3) For the next trial, the process was repeated, with the subject selecting a finger span and matching to it a weight that was placed in container No. 2 .

The two subjects in Experiment 1 took 4 and $2 \mathrm{~h}$, respectively, to complete the tests. The subject taking $4 \mathrm{~h}$ did so on two consecutive evenings, with two 5-min breaks. The subject who took $2 \mathrm{~h}$ did so in one session; two 5-min breaks were also taken.

The subjects in Experiment 2 took an average of $6.5 \mathrm{~h}$ to complete the tests, in two sessions about 5 days apart. They averaged about four 5-min breaks per session.

\section{RESULTS}

For each $A_{2} / B_{1}$ test, the judgment stimulus values $\left(A_{2}\right)$ were plotted on the abscissa against the criterion stimulus values $\left(B_{1}\right)$ on the ordinate, on log$\log$ coordinates. (Because data are not usually plotted this way, the resulting exponent values are the inverse of other experimenters'.)

Exponents (slopes) were determined using linear structural relation analysis. Isaac (1970) pointed out that whenever an interrelation exists between two dependent variables, this method is superior to least squares regression analysis. Variance values on the $x$ - and $y$-axes were assumed to be equal in this experiment (Stevens, 1971); therefore, the appropriate equation was: 


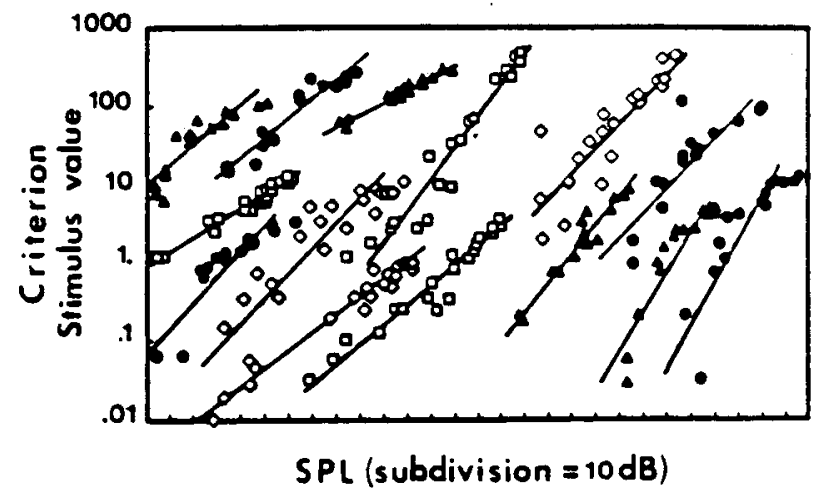

Figure 1. All individual functions in which tone was a judgment stimulus. Diamonds and squares represent functions for Subjects 1 and 2, respectively, for Experiment 1. Triangles and circles represent functions for Subjects 1 and 2, respectively, for Experiment 2. Note the downward curvilinearity of 5 of the 14 functions.

$B=\frac{\operatorname{var} y-\lambda \operatorname{var} x+\left[(\operatorname{var} y-\lambda \operatorname{var} x)^{2}+4 \operatorname{cov}^{2}(x, y)\right]^{1 / 2}}{2 \operatorname{cov}(x, y)}$,

with $o_{\mathrm{cy}}^{2} / \sigma_{\varepsilon \mathrm{x}}^{2}=1$.

Figures 1 through 3 show the plots of all 64 functions, and their slopes. Figure 1 shows all the functions in which sound intensity was the judgment stim- ulus. Diamonds and squares represent functions for Subjects 1 and 2, respectively, for Experiment 1 . Triangles and circles represent functions for Subjects 1 and 2, respectively, for Experiment 2. The position of each function is arbitrary along the abscissa; this is also true in Figures 2 and 3. Note that five of the functions are concave downward, and that these functions belong to subjects in Experiment 2 in which tones were presented monaurally-SPL/ number (Subjects 1 and 2), SPL/line (Subject 2), and SPL/finger span (Subjects 1 and 2). The SPLs selected ranged from about 20 to $100 \mathrm{~dB}$. Figure 2 shows all the functions in which sound intensity was the criterion stimulus. Note that four of the functions are concave upward and that again they belong to the subjects in Experiment 2. Showing an upward curvilinearity are the matches of number/SPL (Subjects 1 and 2), line/SPL (Subject 2), and finger span/SPL (Subject 1). The stimulus values ranged from -1.5 to $2.7 \mathrm{log}$ units. Figure 3 shows the remaining 38 functions. Note that most of the functions show good to excellent fit. Although correlation as an index of fit of a function is not entirely appropriate in this case, it can suggest a relation between two variables. For all 64 functions, the mean Pearson product-moment correlation $\mathrm{r}=.95\left(\mathrm{r}^{2}=\right.$ .90). It seems that when the subject controls both

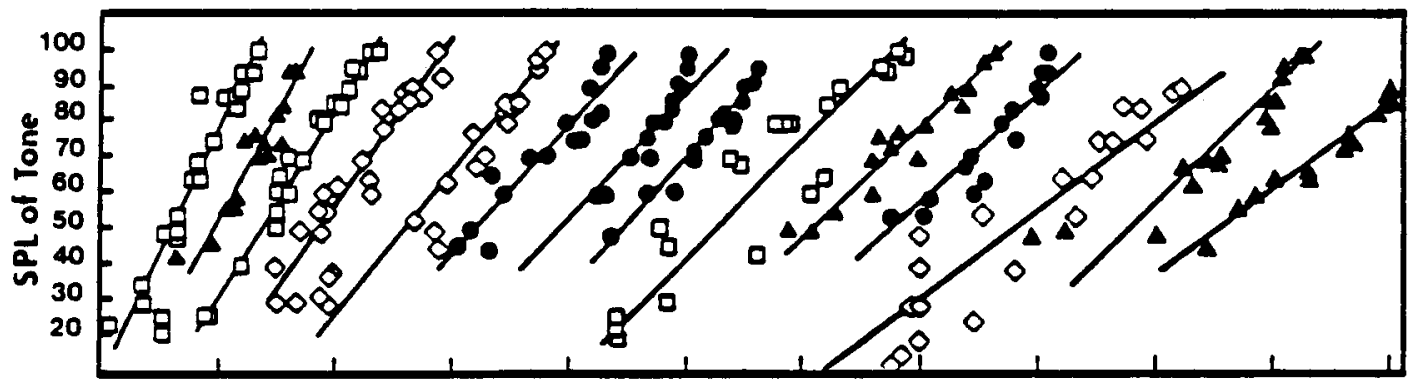

Stimulus value (subdivision $=1 \mathrm{log}$ )

Figure 2. All individual functions in which tone was the criterion stimulus. Note the four functions that display upward curvilinearity and, as in Figure 1, belong to Subjects 1 and 2 of Experiment 2.

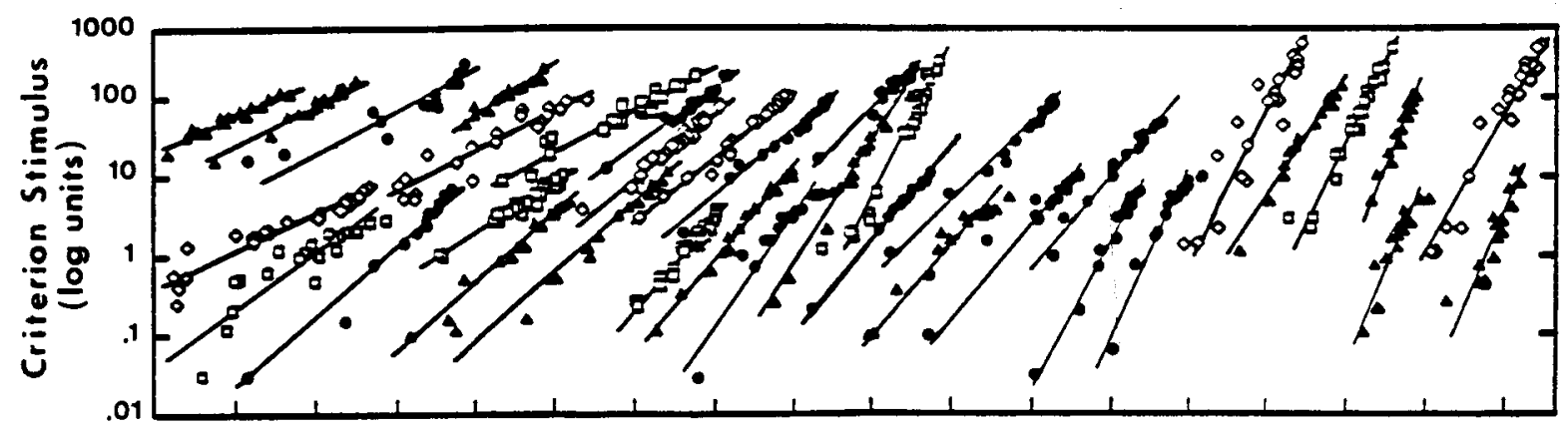

Judgment Stimulus (log units)

Figure 3. The remaining 38 of the 64 functions. 
judgment and criterion stimuli, the resulting individual matching functions are as orderly as those obtained when the experimenter controls the criterion stimulus.

\section{Regression Effect}

Table 1 shows all obtained exponents. If there is no regression effect, when the exponent for $B_{2} / A_{1}$ is $j$, the exponent $i$ for $A_{2} / B_{1}$ should be equal to $1 / j$. The data in Table 1 were analyzed by taking, for each $\mathrm{AB}$ pair, the difference between $\log \mathrm{i}$ and $\log 1 / \mathrm{j}$; the mean of the $\log$ deviations was +.05 , and the standard deviation was .13. Thus, these data indicate a small regression effect even when the subject controls both stimuli.

Figures 4 and 5 show the relation between the exponents $i$ and $1 / j$ for continua number and SPL, respectively. For both figures, the continuum as

Table 1

Individual Exponents for Cross-Modal Matches

\begin{tabular}{|c|c|c|c|c|}
\hline \multirow{2}{*}{$\begin{array}{c}\text { Criterion } \\
\text { Judgment }\end{array}$} & \multicolumn{2}{|c|}{ Experiment 1} & \multicolumn{2}{|c|}{ Experiment 2} \\
\hline & Subject 1 & Subject 2 & Subject 1 & Subject 2 \\
\hline \multicolumn{5}{|c|}{ Line $^{*}$} \\
\hline $\begin{array}{l}\text { Luminance } \\
\text { Number } \\
\text { SPL } \\
\text { Weight } \\
\text { Finger Span }\end{array}$ & $\begin{array}{l}.49 \\
.82 \\
.66\end{array}$ & $\begin{array}{r}.72 \\
1.20 \\
.49\end{array}$ & $\begin{array}{r}.89 \\
.76 \\
2.25 \\
1.21\end{array}$ & $\begin{array}{l}1.14 \\
1.06 \\
2.19 \\
1.10\end{array}$ \\
\hline \multicolumn{5}{|c|}{ Number } \\
\hline $\begin{array}{l}\text { Luminance } \\
\text { SPL } \\
\text { Length } \\
\text { Weight } \\
\text { Finger Span }\end{array}$ & $\begin{array}{l}.51 \\
.46 \\
.82\end{array}$ & $\begin{array}{l}.54 \\
.36 \\
.64\end{array}$ & $\begin{array}{r}.49 \\
1.55 \\
2.33 \\
1.60\end{array}$ & $\begin{array}{r}.66 \\
.99 \\
1.16 \\
.85\end{array}$ \\
\hline \multicolumn{5}{|c|}{ Luminance } \\
\hline $\begin{array}{l}\text { Number } \\
\text { SPL } \\
\text { Length }\end{array}$ & $\begin{array}{r}2.06 \\
.66 \\
1.83\end{array}$ & $\begin{array}{r}2.02 \\
.79 \\
1.94\end{array}$ & & \\
\hline \multicolumn{5}{|c|}{ SPL** } \\
\hline $\begin{array}{l}\text { Luminance } \\
\text { Number } \\
\text { Length } \\
\text { Weight } \\
\text { Finger Span }\end{array}$ & $\begin{array}{l}1.40 \\
2.34 \\
1.97\end{array}$ & $\begin{array}{l}1.65 \\
3.60 \\
2.55\end{array}$ & $\begin{array}{l}1.21 \\
1.54 \\
3.08 \\
1.22\end{array}$ & $\begin{array}{l}1.76 \\
1.48 \\
1.80 \\
1.67\end{array}$ \\
\hline \multicolumn{5}{|c|}{ Weight } \\
\hline $\begin{array}{l}\text { Number } \\
\text { SPL } \\
\text { Length } \\
\text { Finger Span }\end{array}$ & & & $\begin{array}{l}.62 \\
.31 \\
.46 \\
.46\end{array}$ & $\begin{array}{l}.99 \\
.55 \\
.72 \\
.50\end{array}$ \\
\hline \multicolumn{5}{|c|}{ Finger Span } \\
\hline $\begin{array}{l}\text { Number } \\
\text { SPL } \\
\text { Length } \\
\text { Weight }\end{array}$ & . & & $\begin{array}{l}.88 \\
1.01 \\
1.07 \\
2.46\end{array}$ & $\begin{array}{r}1.48 \\
.65 \\
.87 \\
1.93\end{array}$ \\
\hline
\end{tabular}

Note-Exponents were obtained by plotting judgmental values on the abscissa, criterial values on the ordinate. "Paper size was $7 \mathrm{~cm}$ shorter in Experiment 1 than in Experiment $2 .{ }^{* *}$ Tones were presented binaurally in Experiment 1, monaurally in Experiment 2.

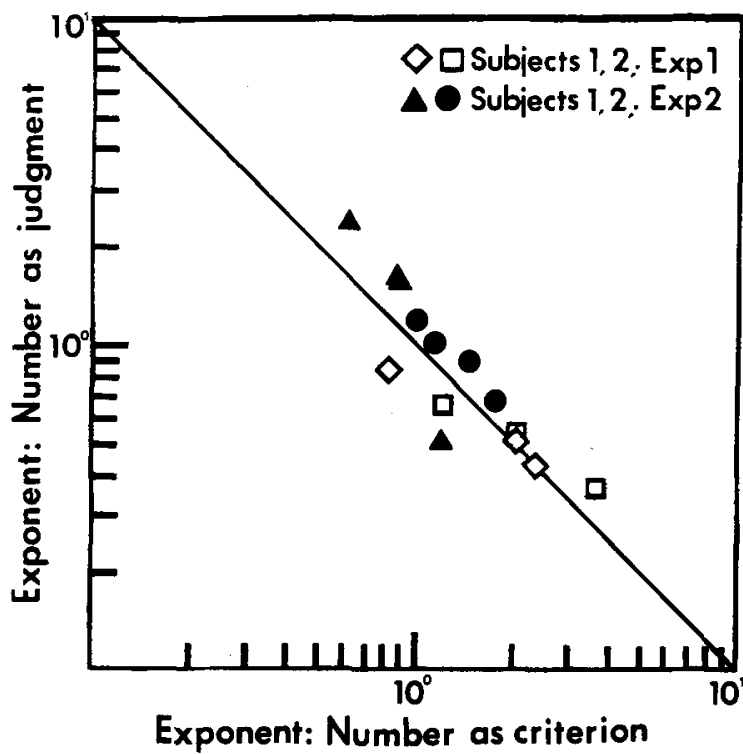

Figure 4. Comparison of exponents 1 and $1 / \mathrm{j}$ for matches $A_{2} / B_{1}$ and $B_{2} / A_{1}$, with respect to number. Number as a judgmental stimulus $\left(A_{2}\right)$ is plotted on the abseissa against number as a criterial stimalus $\left(A_{1}\right)$, on the ordinate.

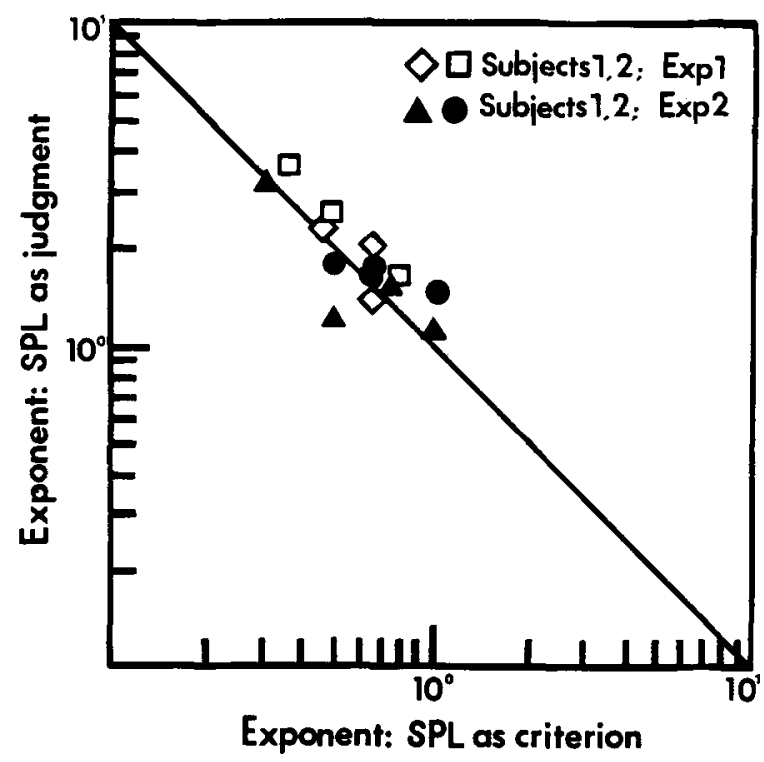

Figure 5. Comparison of exponents 1 and $1 / \mathrm{J}$ for matches $A_{2} / B_{1}$ and $B_{2} / A_{1}$, with reapect to SPL. SPL as judgmental stimulus is plotted on the abscissa against SPL as a criterial stimulus on the ordinate.

judgmental $\left(A_{2}\right)$ is plotted on the abscissa against the continuum as criterial $\left(A_{1}\right)$ on the ordinate. Figure 4 shows the exponent $i$ for magnitude estimation to be greater than the exponent $1 / \mathrm{j}$ for magnitude production in 11 of 14 cases $(79 \%)$. Figure 5 shows $i$ greater than $1 / j$ in 10 of 14 cases $(71 \%)$. Both number and SPL exhibit a similar regression effect. 
Table 2

Mean Judgmental and Criterial Ranges (Log Units) Set by Subjects

\begin{tabular}{|c|c|c|c|c|c|c|c|c|}
\hline & \multicolumn{4}{|c|}{ Experiment 1} & \multicolumn{4}{|c|}{ Experiment 2} \\
\hline & \multicolumn{2}{|c|}{ Subject 1} & \multicolumn{2}{|c|}{ Subject 2} & \multicolumn{2}{|c|}{ Subject 1} & \multicolumn{2}{|c|}{ Subject 2} \\
\hline & Criterion & Judgment & Criterion & Judgment & Criterion & Judgment & Criterion & Judgment \\
\hline Luminance & 2.51 & 2.49 & 2.42 & 2.31 & & & & \\
\hline Length & 1.56 & 1.86 & 1.50 & 1.62 & 1.85 & 1.66 & 2.15 & 2.04 \\
\hline SPL & 3.67 & 3.55 & 3.93 & 3.51 & 2.49 & 2.42 & 2.66 & 2.69 \\
\hline Number & 1.60 & 1.52 & 1.10 & 1.20 & 1.80 & 1.90 & 1.85 & 1.49 \\
\hline Finger Span & & & & & 1.86 & 1.75 & 2.02 & 2.04 \\
\hline Weight & & & & & .81 & .84 & 1.22 & 1.28 \\
\hline
\end{tabular}

The criterial and judgmental stimulus ranges were examined; Table 2 shows the mean values. In 10 of the 18 instances $(55 \%)$, the mean criterial range was larger than the mean judgmental range for a given continuum. The average stimulus range was 2.03 log units; criterial stimulus ranges averaged $2.05 \mathrm{log}$ units, and the judgmental stimulus ranges averaged $2.01 \log$ units. Criterial stimulus ranges were from .81 to $3.93 \log$ units; judgmental stimulus ranges were from 1.2 to $3.55 \mathrm{log}$ units.

The subjects increased the range of a stimulus when it switched identities from judgmental to criterial and, likewise, decreased the range of a stimulus when it switched identities from criterial to judgmental, about half the time $(56 \%$ and $53 \%$, respectively). Examination of individual stimulus ranges does indicate a regression effect, but it is rather small and inconsistent.

\section{Transitivity of Exponents}

To determine how consistently the subjects judged each continuum, exponents for each $A_{2} / B_{1}$ match were compared with ratios of exponents from other matches using that continuum. For example, given three continua, $A, B$, and $C$, and matches $A_{2} / C_{1}$ and $B_{2} / C_{1}$, with their respective exponents $g$ and $h$,

Table 3

Deviations of Predicted Exponents From Obtained Exponents in Experiment 1

\begin{tabular}{|c|c|c|c|c|c|c|c|c|}
\hline \multirow[b]{2}{*}{$A_{2} / B_{1}$} & \multicolumn{2}{|c|}{ Tone } & \multicolumn{2}{|c|}{ Line } & \multicolumn{2}{|c|}{ Number } & \multicolumn{2}{|c|}{ Light } \\
\hline & Subject 1 & Subject 2 & Subject 1 & Subject 2 & Subject 1 & Subject 2 & Subject 1 & Subject 2 \\
\hline Tone/Line & & & & & $\begin{array}{l}-.05 \\
-.27\end{array}$ & $\begin{array}{r}+.06 \\
-.17\end{array}$ & $\begin{array}{l}-.24 \\
-.27\end{array}$ & $\begin{array}{l}-.08 \\
-.05\end{array}$ \\
\hline Tone/Number & & & $\begin{array}{l}+.24 \\
-.04\end{array}$ & $\begin{array}{l}+.05 \\
-.16\end{array}$ & & & $\begin{array}{l}-.15 \\
-.10\end{array}$ & $\begin{array}{l}+.03 \\
-.04\end{array}$ \\
\hline Tone/Light & & & $\begin{array}{l}+.31 \\
+.13\end{array}$ & $\begin{array}{l}-.07 \\
-.02\end{array}$ & $\begin{array}{l}+.13 \\
+.13\end{array}$ & $\begin{array}{l}-.08 \\
-.15\end{array}$ & & \\
\hline Line/Tone & & & & & $\begin{array}{l}-.05 \\
+.16\end{array}$ & $\begin{array}{l}-.16 \\
+.07\end{array}$ & $\begin{array}{l}+.13 \\
+.17\end{array}$ & $\begin{array}{l}+.02 \\
-.05\end{array}$ \\
\hline Line/Number & $\begin{array}{l}+.01 \\
-.06\end{array}$ & $\begin{array}{l}+.04 \\
+.05\end{array}$ & & & & & $\begin{array}{l}+.01 \\
+.11\end{array}$ & $\begin{array}{l}+.17 \\
+.05\end{array}$ \\
\hline Line/Light & $\begin{array}{l}-.10 \\
-.24\end{array}$ & $\begin{array}{l}-.10 \\
-.08\end{array}$ & & & $\begin{array}{l}-.03 \\
+.16\end{array}$ & $\begin{array}{l}-.11 \\
-.06\end{array}$ & & . \\
\hline Number/Tone & & & $\begin{array}{l}-.27 \\
+.01\end{array}$ & $\begin{array}{l}-.17 \\
+.04\end{array}$ & & & $\begin{array}{l}+.12 \\
+.07\end{array}$ & $\begin{array}{l}-.15 \\
-.07\end{array}$ \\
\hline Number/Line & $\begin{array}{l}+.17 \\
+.25\end{array}$ & $\begin{array}{l}+.07 \\
+.05\end{array}$ & & & & $i$ & $\begin{array}{l}+.17 \\
+.07\end{array}$ & $\begin{array}{r}-.06 \\
+.04\end{array}$ \\
\hline Number/Light & $\begin{array}{l}-.09 \\
-.15\end{array}$ & $\begin{array}{l}+.03 \\
+.03\end{array}$ & $\begin{array}{l}-.09 \\
+.01\end{array}$ & $\begin{array}{r}-.09 \\
+.17\end{array}$ & & & & \\
\hline Light/Tone & & & $\begin{array}{l}-.28 \\
-.09\end{array}$ & $\begin{array}{l}-.05 \\
-.10\end{array}$ & $\begin{array}{l}-.10 \\
-.09\end{array}$ & $\begin{array}{l}-.04 \\
+.03\end{array}$ & & \\
\hline Light/Line & $\begin{array}{l}+.16 \\
+.31\end{array}$ & $\begin{array}{l}-.05 \\
-.06\end{array}$ & & & $\begin{array}{l}+.11 \\
-.07\end{array}$ & $\begin{array}{l}+.06 \\
-.09\end{array}$ & 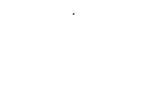 & \\
\hline Light/Number & $\begin{array}{l}+.07 \\
+.13\end{array}$ & $\begin{array}{l}-.07 \\
-.07\end{array}$ & $\begin{array}{l}+.07 \\
-.03\end{array}$ & $\begin{array}{l}+.07 \\
-.21\end{array}$ & & & & \\
\hline Median & $\begin{array}{r}+.04 \\
+.04 \\
\end{array}$ & $\begin{array}{l}-.01 \\
-.02 \\
\end{array}$ & $\begin{array}{l}-.01 \\
-.01 \\
\end{array}$ & $\begin{array}{l}-.06 \\
-.06 \\
\end{array}$ & $\begin{array}{r}-.04 \\
+.03 \\
\end{array}$ & $\begin{array}{l}-.06 \\
-.08 \\
\end{array}$ & $\begin{array}{r}+.07 \\
+.07 \\
\end{array}$ & $\begin{array}{l}-.02 \\
-.05 \\
\end{array}$ \\
\hline
\end{tabular}


the predicted exponent for an $\mathrm{AB}$ match is $\mathrm{g} / \mathrm{h}$. Similarly, given matches $C_{2} / A_{1}$ and $C_{2} / B_{1}$, with their respective exponents $m$ and $n$, the predicted exponent is $\mathbf{n} / \mathrm{m}$.

Table 3 shows the differences between obtained and predicted exponents for Experiment 1; Table 4 shows them for Experiment 2. In each table, the row headings indicate the $A_{2} / B_{1}$ combination that gives the obtained exponent $i$, and the column headings indicate $\mathrm{C}$, which, in combination with $\mathrm{A}$ and $\mathrm{B}$, give the predicted exponents $\mathrm{g} / \mathrm{h}$ and $\mathrm{n} / \mathrm{m}$. The cell entries are $\log i-\log (g / h)$ in the first row and $\log i-$ $\log (\mathrm{n} / \mathrm{m})$ in the second row for each subject. The median $\log$ deviation in Table 3 is .035 , the interquartile range is -.09 to +.07 , and the range is -.28 to $+.31(-.09$ represents an obtained exponent $19 \%$ smaller than the predicted, and +.07 represents one $17 \%$ larger than the predicted). The median log de-

Table 4

Deviations of Predicted Exponents From Obtained Exponents in Experiment 2

\begin{tabular}{|c|c|c|c|c|c|c|c|c|c|c|}
\hline \multirow[b]{2}{*}{$A_{2} / B_{1}$} & \multicolumn{2}{|c|}{ Tone } & \multicolumn{2}{|c|}{ Finger Span } & \multicolumn{2}{|c|}{ Line } & \multicolumn{2}{|c|}{ Number } & \multicolumn{2}{|c|}{ Weight } \\
\hline & Subject 1 & Subject 2 & Subject 1 & Subject 2 & Subject 1 & Subject 2 & Subject 1 & Subject 2 & Subject 1 & Subject 2 \\
\hline Tone/Finger Span & & & & & $\begin{array}{l}-.20 \\
-.15\end{array}$ & $\begin{array}{l}+.15 \\
-.04\end{array}$ & $\begin{array}{l}-.52 \\
-.14\end{array}$ & $\begin{array}{l}+.08 \\
+.11\end{array}$ & $\begin{array}{l}-.17 \\
-.10\end{array}$ & $\begin{array}{r}+.19 \\
+.21\end{array}$ \\
\hline Tone/Line & & & $\begin{array}{l}+.10 \\
+.12\end{array}$ & $\begin{array}{l}-.15 \\
-.21\end{array}$ & & & $\begin{array}{l}-.37 \\
-.01\end{array}$ & $\begin{array}{l}-.20 \\
-.22\end{array}$ & $\begin{array}{r}-.04 \\
-.02\end{array}$ & $\begin{array}{r}-.19 \\
+.06\end{array}$ \\
\hline Tone/Number & & & $\begin{array}{l}+.37 \\
+.42\end{array}$ & $\begin{array}{l}-.18 \\
-.11\end{array}$ & $\begin{array}{r}+.24 \\
+.31\end{array}$ & $\begin{array}{l}+.15 \\
+.01\end{array}$ & & & $\begin{array}{l}+.01 \\
+.19\end{array}$ & $\begin{array}{l}-.12 \\
-.01\end{array}$ \\
\hline Tone/Weight & & & $\begin{array}{l}+.14 \\
+.09\end{array}$ & $\begin{array}{l}-.17 \\
-.22\end{array}$ & $\begin{array}{l}+.04 \\
-.03\end{array}$ & $\begin{array}{l}-.02 \\
-.01\end{array}$ & $\begin{array}{r}-.17 \\
+.21\end{array}$ & $\begin{array}{l}+.05 \\
+.05\end{array}$ & & \\
\hline Finger Span/Tone & & & & & $\begin{array}{l}+.11 \\
+.07\end{array}$ & $\begin{array}{l}-.20 \\
+.01\end{array}$ & $\begin{array}{l}+.42 \\
+.05\end{array}$ & $\begin{array}{l}-.11 \\
-.14\end{array}$ & $\begin{array}{l}+.08 \\
+.01\end{array}$ & $\begin{array}{l}+.22 \\
-.25\end{array}$ \\
\hline Finger Span/Line & $\begin{array}{l}-.18 \\
-.20\end{array}$ & $\begin{array}{l}+.01 \\
+.17\end{array}$ & & & & & $\begin{array}{l}-.07 \\
-.08\end{array}$ & $\begin{array}{l}-.11 \\
-.15\end{array}$ & $\begin{array}{l}+.08 \\
-.12\end{array}$ & $\begin{array}{r}-.20 \\
+.01\end{array}$ \\
\hline Finger Span/Number & $\begin{array}{l}-.20 \\
-.52\end{array}$ & $\begin{array}{l}+.05 \\
+.07\end{array}$ & & & $\begin{array}{l}-.07 \\
-.04\end{array}$ & $\begin{array}{l}+.05 \\
+.13\end{array}$ & & & $\begin{array}{l}-.33 \\
-.22\end{array}$ & $\begin{array}{l}-.23 \\
-.29\end{array}$ \\
\hline Finger Span/Weight & $\begin{array}{l}-.06 \\
-.17\end{array}$ & $\begin{array}{l}+.27 \\
+.19\end{array}$ & & & $\begin{array}{l}+.07 \\
-.04\end{array}$ & $\begin{array}{r}.00 \\
+.19\end{array}$ & $\begin{array}{r}+.18 \\
+.19\end{array}$ & $\begin{array}{l}+.16 \\
+.13\end{array}$ & & \\
\hline Line/Tone & & & $\begin{array}{l}-.17 \\
-.06\end{array}$ & $\begin{array}{r}-.04 \\
+.01\end{array}$ & & & $\begin{array}{l}+.31 \\
-.19\end{array}$ & $\begin{array}{l}+.01 \\
+.02\end{array}$ & $\begin{array}{l}-.03 \\
-.05\end{array}$ & $\begin{array}{l}-.01 \\
-.26\end{array}$ \\
\hline Line/Finger Span & $\begin{array}{r}+.07 \\
+.09\end{array}$ & $\begin{array}{l}-.02 \\
-.18\end{array}$ & & & & & $\begin{array}{l}-.04 \\
-.03\end{array}$ & $\begin{array}{r}+.09 \\
+.14\end{array}$ & $\begin{array}{l}-.03 \\
+.01\end{array}$ & $\begin{array}{l}+.19 \\
-.03\end{array}$ \\
\hline Line/Number & $\begin{array}{l}-.09 \\
-.38\end{array}$ & $\begin{array}{l}-.08 \\
-.20\end{array}$ & $\begin{array}{l}-.11 \\
-.07\end{array}$ & $\begin{array}{l}-.23 \\
-.11\end{array}$ & & & & & $\begin{array}{l}-.33 \\
-.17\end{array}$ & $\begin{array}{l}-.14 \\
-.28\end{array}$ \\
\hline Line/Weight & $\begin{array}{l}+.05 \\
-.04\end{array}$ & $\begin{array}{l}+.05 \\
-.19\end{array}$ & $\begin{array}{l}-.02 \\
-.07\end{array}$ & $\begin{array}{l}-.17 \\
-.21\end{array}$ & & & $\begin{array}{l}+.17 \\
+.20\end{array}$ & $\begin{array}{r}-.07 \\
+.08\end{array}$ & & \\
\hline Number/Tone & & & $\begin{array}{l}-.14 \\
-.20\end{array}$ & $\begin{array}{l}+.11 \\
+.05\end{array}$ & $\begin{array}{l}-.01 \\
-.08\end{array}$ & $\begin{array}{l}-.22 \\
-.08\end{array}$ & & & $\begin{array}{l}+.12 \\
+.04\end{array}$ & $\begin{array}{l}+.05 \\
+.06\end{array}$ \\
\hline Number/Finger Span & $\begin{array}{l}+.06 \\
+.37\end{array}$ & $\begin{array}{l}-.15 \\
-.17\end{array}$ & & & $\begin{array}{l}-.07 \\
-.10\end{array}$ & $\begin{array}{l}-.16 \\
-.23\end{array}$ & & & $\begin{array}{r}+.19 \\
+.09\end{array}$ & $\begin{array}{l}+.13 \\
+.05\end{array}$ \\
\hline Number/Line & $\begin{array}{r}-.05 \\
+.24\end{array}$ & $\begin{array}{l}+.02 \\
+.15\end{array}$ & $\begin{array}{l}-.04 \\
-.07\end{array}$ & $\begin{array}{r}+.14 \\
+.05\end{array}$ & & & & & $\begin{array}{l}+.10 \\
-.04\end{array}$ & $\begin{array}{l}+.08 \\
+.22\end{array}$ \\
\hline Number/Weight & $\begin{array}{r}-.20 \\
+.01\end{array}$ & $\begin{array}{r}.00 \\
-.12\end{array}$ & $\begin{array}{l}-.23 \\
-.33\end{array}$ & $\begin{array}{l}-.11 \\
-.23\end{array}$ & $\begin{array}{l}-.19 \\
-.33\end{array}$ & $\begin{array}{l}-.28 \\
-.14\end{array}$ & & & & \\
\hline Weight/Tone & & & $\begin{array}{l}-.10 \\
-.07\end{array}$ & $\begin{array}{r}-.21 \\
+.26\end{array}$ & $\begin{array}{r}-.02 \\
+.04\end{array}$ & $\begin{array}{l}+.06 \\
+.05\end{array}$ & $\begin{array}{l}+.19 \\
-.20\end{array}$ & $\begin{array}{l}-.01 \\
-.01\end{array}$ & & \\
\hline Weight/Finger Span & $\begin{array}{l}+.01 \\
+.12\end{array}$ & $\begin{array}{l}-.26 \\
-.18\end{array}$ & & & $\begin{array}{l}-.12 \\
-.01\end{array}$ & $\begin{array}{l}+.01 \\
-.21\end{array}$ & $\begin{array}{l}-.23 \\
-.24\end{array}$ & $\begin{array}{l}-.16 \\
-.12\end{array}$ & & \\
\hline Weight/Line & $\begin{array}{r}-.05 \\
+.04\end{array}$ & $\begin{array}{l}-.26 \\
-.01\end{array}$ & $\begin{array}{l}+.01 \\
+.06\end{array}$ & $\begin{array}{l}.00 \\
.00\end{array}$ & & & $\begin{array}{l}-.17 \\
-.19\end{array}$ & $\begin{array}{l}-.27 \\
-.28\end{array}$ & & \\
\hline Weight/Number & $\begin{array}{r}+.14 \\
-.17\end{array}$ & $\begin{array}{r}-.05 \\
+.06\end{array}$ & $\begin{array}{r}+.07 \\
+.17\end{array}$ & $\begin{array}{l}+.05 \\
+.17\end{array}$ & $\begin{array}{r}+.03 \\
+.17\end{array}$ & $\begin{array}{l}+.22 \\
-.08\end{array}$ & & & & \\
\hline Median & $\begin{array}{l}-.05 \\
-.02 \\
\end{array}$ & $\begin{array}{l}-.01 \\
-.06 \\
\end{array}$ & $\begin{array}{l}-.03 \\
-.06 \\
\end{array}$ & $\begin{array}{l}-.13 \\
-.06 \\
\end{array}$ & $\begin{array}{l}-.02 \\
-.04 \\
\end{array}$ & $\begin{array}{l}+.01 \\
-.03 \\
\end{array}$ & $\begin{array}{l}-.06 \\
-.06 \\
\end{array}$ & $\begin{array}{r}-.04 \\
+.01 \\
\end{array}$ & $\begin{array}{l}-.01 \\
-.03 \\
\end{array}$ & $\begin{array}{l}+.03 \\
+.02 \\
\end{array}$ \\
\hline
\end{tabular}




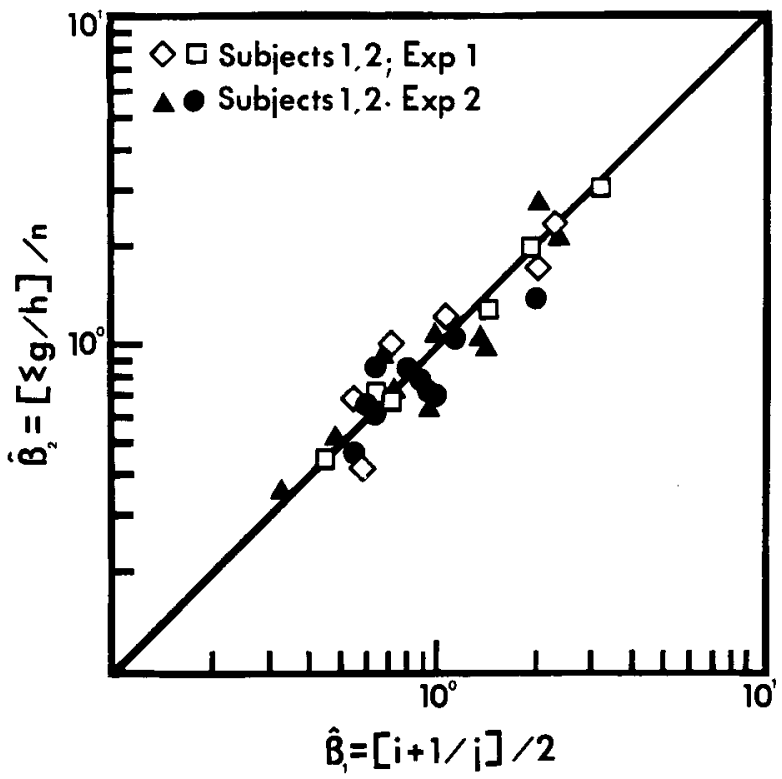

Figure 6. Comparison of the mean predictor ratios $\hat{\mathbf{B}}_{2}=$ $(\Sigma g / h) / n$ on the ordinate, with $\hat{B}_{1}=(i+1 / j) / 2$ on the abscissa.

viation in Table 4 is .025 , the interquartile range is -.17 to +.07 , the range is -.52 to +.42 . Although in individual cases there are some rather striking failures of prediction, overall these individual exponents exhibit a transitivity that has been claimed for group exponents.

When, for each individual, an average is taken across the $\mathrm{AC}$ and $\mathrm{BC}$ combinations, transitivity is demonstrated even more clearly. For Experiment 1, for each $\mathrm{AB}$ exponent there were four predictor ratios; Experiment 2 had six. Figure 6 shows the mean predictor ratio value for each $\mathrm{AB}$ match on the ordinate, with the value $(i+1 / j) / 2$ (which represents a more stable estimate of the $\mathrm{AB}$ exponent) plotted on the abscissa. The mean predicted value exceeded the obtained value in exactly 16 of the 32 cases $(50 \%)$, and the points cluster fairly closely around the line representing perfect prediction.

\section{DISCUSSION}

This study indicates that allowing the subject to control both criterion and judgment stimuli results in agreement both between $\mathrm{AB}$ and $\mathrm{BA}$ exponents, and between $A C$ and $B C$ exponents, on the one hand, and $A B$ exponents, on the other. With regard to the former, control of both stimuli does not eliminate the regression effect, as was expected; however, the effect is minimized. With regard to the latter, individual exponents do exhibit transitivity.
The fact that subjects using tones presented monaurally (Experiment 2) produced curvilinear functions suggests that binaurally presented tones should be used in CMM experiments unless the upper limit is increased beyond $100 \mathrm{~dB}$ or so.

It is difficult to make any generalizations about the results of this study until similar studies, also giving subjects control of both stimuli, are conducted. It is of interest to note why experimenters who have conducted previous CMM experiments (with the exception of Stevens \& Guirao) have not given subjects control of both stimuli. An obvious reason is that it is easier to make intersubject comparisons when the criterion stimulus values are the same for each subject. This study suggests that for some subjects, however, the stimulus values presented by the experimenter are not necessarily the values that he/ she would "naturally" choose. Because of this possibility, exponents obtained by the traditional CMM procedure may be inaccurate. In addition, the power law holds that, because of the sensory operating characteristics of the subject, consistent judgments for a given modality can be expected. It seems likely that sensory operating characteristics differ more or less from subject to subject. Therefore, groupaverage exponents, while balancing out in the long run, would tend to camouflage individual trends. This, coupled with subjects' differing preferences for criterion stimulus values, suggests (1) that subjects be given control of both stimuli, and (2) that individual exponents be examined.

\section{REFERENCES}

IsAAc, P. D. Linear structural relations and measurement error. Psychological Bulletin, 1970, 74, 213-218.

Mashour, M., \& Hosman, J. On the new "psychophysical law": A validation study. Perception \& Psychophysics, 1968, 3, 367. 375.

Stevens, J. C., \& Guirao, M. Individual loudness functions. Journal of the Acoustical Society of America, 1964, 36, 21102213.

Stevens, S. S. On predicting exponents for cross-modality matches. Perception \& Psychophysics, 1969, 6, 251-256.

Stevens, S. S. Issues in psychophysical measurement. Psychophysical Review, 1971, 78, 426-449.

Stevens, S. S. Psychophysics. New York: Wiley, 1975.

Stevens, S. S., \& Greenbaum, H. B. Regression effect in psychophysical judgment. Perception \& Psychophysics, 1966, 1, 439-446.

Teghtsoonian, R., \& Teghtsoonian, M. Range and regression effects in magnitude scaling. Perception \& Psychophysics, 1978, 24, 305-314.

(Manuscript received August 20, 1981; revision accepted for publication February 1, 1983.) 